\title{
PEDIATRIC DENTISTRY DURING ROOMING-IN CARE: EVALUATION OF AN INNOVATIVE PROJECT FOR PROMOTING ORAL HEALTH
}

\author{
ODONTOPEDIATRIA NO ALOJAMENTO CONJUNTO: AVALIAÇÃO DE UM PROJETO \\ INOVADOR EM PROMOÇÃO DE SAÚDE BUCAL
}

Giovanna Pires da Silva Ribeiro de REZENDE ${ }^{1}$, Luciane Ribeiro de Rezende Sucasas da COSTA ${ }^{2}$, Regina Aparecida CARDOSO ${ }^{3}$

\author{
1- Master's degree candidate, Health Sciences Program, University of Brasilia, Federal University of Goias (UFG). \\ and Federal University of Mato Grosso do Sul. \\ 2- Professor of Pediatric Dentistry, Dental School, UFG. \\ 3- Dentist in private practice, Goias. \\ Corresponding address: Luciane Ribeiro de Rezende Sucasas da Costa - Rua J-34 Qd.60 Lt.12 Setor Jaó - Goiânia-GO - Cep: $74673-520$ \\ Phone: (62)204-4075 - e-mail: plcosta@terra.com.br \\ Received: October 10, 2003 - Returned for modification: January 07, 2004 - Accepted: February 13, 2004
}

\begin{abstract}
A

ccording to the current paradigm for promoting health, dental care should be a consideration from the first months of life, or even before birth. The aim of this paper is to evaluate mothers' knowledge of and attitude toward their babies' oral health after receiving guidance during the neonatal period. Forty-six mothers were contacted and asked about the advice they had received and how they felt about the information provided. The mothers recruited for the study were divided into two groups, A $(n=25)$ and $B(n=21)$, according to the time elapsed since their participation in the project, that is, less than or equal to three months and more than three months, respectively. A Wilcoxom rank sum test did not show any statistically significant difference between the two groups ( $>0.05$ ). Guidance on the baby’s oral hygiene, breastfeeding the baby exclusively until the sixth month, as well as the restrictions imposed on sugar intake were what the mothers remembered most. Recommendations concerning good arch development and the use of bottles were what mothers remembered least. Regarding infant oral health, it would be advisable to schedule prenatal and neonatal visits, with the second post-natal consultation no later than four months after childbirth.
\end{abstract}

UNITERMS: Health promotion; Dental caries; Breastfeeding.

\footnotetext{
RESUMO

S

egundo o paradigma atual de promoção de saúde, a atenção odontológica deve se iniciar ainda nos primeiros meses de vida ou então anteriormente ao nascimento, já que hábitos alimentares e de higiene bucal se estabelecem muito cedo. Avaliouse o grau de conhecimento e as atitudes das mães com relação à saúde bucal do bebê, após as mesmas terem recebido orientações no período neonatal (projeto “Odontopediatria no alojamento conjunto”/ UFG). Quarenta e seis mães com idades de 15 a 38 anos foram questionadas a respeito das orientações recebidas, bem como seu comportamento em relação às mesmas. Dividiu-se a casuística em dois grupos, $A(n=25)$ e $B(n=21)$, de acordo com o tempo decorrido após a implementação do projeto, ou seja, menor ou igual a três meses e maior que três meses, respectivamente. Frente às orientações recebidas (transmissibilidade da cárie dentária, hábitos alimentares, desenvolvimento das arcadas e higiene bucal), a análise de variância não mostrou diferenças estatisticamente significantes entre os dois grupos ( $>>0,05)$, no que diz respeito ao conhecimento e atitudes das mães. As orientações de higiene bucal do bebê, de aleitamento materno exclusivo até seis meses e a restrição na ingestão de açúcar foram as mais lembradas pelas mães. Recomendações referentes à contribuição ao bom desenvolvimento das arcadas e às precauções quanto ao uso de mamadeiras foram menos recordadas. Considerando a saúde bucal do lactente, seria aconselhável que cuidadores sejam orientados nos períodos pré- e neonatal, sendo que a segunda consulta odontológica pósnascimento deve idealmente ocorrer por volta do quarto mês de vida da criança.

UNITERMOS: Promoção de saúde; Higiene bucal; Aleitamento materno.
} 


\section{INTRODUCTION}

Certain attitudes related to oral health, such as eating habits and oral hygiene, are established very early in life ${ }^{11}$. Once instilled in children, these hardly ever change ${ }^{14}$.

Thus, mothers are currently acknowledged as the primary promoters and disseminators of oral health ${ }^{4,6,15,16}$. Furthermore, it is extremely important that dental care should begin early, preferably during the first year of life $e^{5,9,15,22}$.

A program called “Lying-In Pediatric Dentistry” (LIPD) has been under way at the Federal University of Goias (UFG) since March 1998. The main objective of this program is to present different aspects of mother and baby oral health to University Hospital (UH) maternity ward patients. This is done by examining the mouth of the neonate and giving onsite orientation sessions, which include oral hygiene maintenance procedures. During these sessions, topics such as breastfeeding, the use of bottles, the transmissibility of caries, consumption of sugar and oral habits, among others, are discussed with each mother, on an individual basis.

In view of the importance of assessing a health program, and of the innovative approach proposed by the LIPD/UFG project, the aim of this study was to evaluate the repercussions of neonatal dental guidance on the knowledge and attitudes of mothers who took part in the program. The hypothesis was that instructed mothers would be concerned about their babies' oral health.

\section{MATERIALAND METHODS}

This study was carried out with 46 mothers, chosen from a population of 180 women seen by the LIPD project. The University Hospital maternity ward follows the protocol of a child-friendly hospital initiative (CFHI), a world-wide campaign which aims at transforming maternity services into breastfeeding-supportive institutions.

Two to six months after receiving the guidance, a sole examiner contacted these mothers by phone and/or made house visits. After verbally consenting to participate in the research, they were interviewed about certain aspects of the transmissibility of dental caries, sugar consumption, occlusal disease prevention (arch development), the baby's oral hygiene, as well as breastfeeding and the use of bottles. Moreover, the examiner asked if the recommendations made during counseling were being followed and, if not, the reason they were not being observed. The mothers were also asked if they knew another family with a newborn baby and if they had passed on the information about oral health received from the University Hospital project team.

The mothers were divided into two groups: A, mothers whose babies were three months old or less; and B, mothers whose babies were older than three months.

The answers to the questionnaires submitted to these two groups (A and B) were tabulated, and a Wilcoxon rank sum test was used to compare the data statistically, taking into consideration the different aspects evaluated (5\% significance level).

\section{RESULTS}

The 46 mothers interviewed ranged in age from 15 to 38 years (mean 22.1 years). There was a total of 18 adolescents, 19 from the 20 to 25 age group and nine were older than 25 . In group A, 25 mothers of 25 babies ranging in age from 2 to 3 months (mean 2.5 months) were evaluated. In group B, 21 mothers participated in the study, and their 21 children were 4 to 6 months of age (mean 4.4 months).

Forty-four mothers said that they remembered the advice they had received from the staff at the UH/UFG, during puerperium, and the two who did not even remember the presence of the Dental School team were excluded. Thus, the results refer to the answers given by 44 mothers (23 from group A and 21 from group B).

Table 1 shows the data related to the variables analyzed. A Wilcoxon test comparing the answers did not show any statistically significant differences between groups A and B ( $>00.05)$.

With regard to sucrose consumption, the mothers who remembered that the baby's diet should be very low in sugar were following this recommendation.

As far as the baby's oral hygiene was concerned, the reasons given by the mothers for not incorporating this habit were the following: the child cried a lot $(n=3)$, they did not think this procedure was important before tooth eruption $(n=2)$, one was afraid of hurting the child $(n=1)$, one was too lazy to do it $(n=1)$, another had a lot to do and did not have enough time $(n=1)$ and still another could not explain why $\operatorname{not}(\mathrm{n}=1)$.

Breastfeeding the baby up to six months of age was a recommendation not followed by six women from group A and seven from group $B$, because they had very little milk $(n=6)$, their milk was weak $(n=3)$, the baby did not accept the breast $(n=3)$, the mother's nipple became sore and cracked $(n=1)$ or because they had to go to work $(n=1)$. One woman from group A and four from group B couldn't help using the bottle.

On the topic of improving the development of the arches, two women from each group said that they gave their children a pacifier for the following reasons: preventing their children from sucking their fingers $(n=2)$, silencing a child who cried excessively and constantly $(n=1)$, and one had no reason.

When asked about the value of this oral health program, $100 \%$ of the mothers gave positive answers.

\section{DISCUSSION}

In a cross-sectional study about caregivers' dental knowledge and attitudes involving 1 - to- 3- year-old children, it was concluded that "it is necessary to promote dental awareness among major caregivers to facilitate early dental check-ups for young children" ${ }^{2}$. Thus, we evaluated a program the major aim of which is to orient lying-in women about different aspects of their neonate's oral health. In the present research, mothers were able to give spontaneous 
statements about the transmissibility of dental caries, the baby's diet, and how they could contribute to the development of the infant child's dental arches.

While evaluating the mothers' behavior and attitudes concerning the caries transmissibility issue, the aspect that came to mind most readily was prohibiting people from kissing the child on the mouth. It is important to emphasize that by kissing the child on the mouth, not only the mutans streptococci, but also several other microorganisms that may cause disease could be transmitted from a parent to a child.

It is also interesting to comment on the fact that, in group $\mathrm{B}$, a higher number of mothers remembered the information about not blowing on the baby's food to cool it. That is probably due to the fact that babies older than six months have other types of meals beside milk, so this recommendation could be applied in the family's daily routine.

A tendency was observed for the mothers to forget the advice to restrict sugar intake as time went on. This result suggests the need to schedule preventive dental visits even before the first tooth appears in order to remind mothers about adequate weaning, since eating habits are established early in the life of a child ${ }^{11,18}$.

Sugar comsumption is a matter of concern for all health professionals. So the present report agrees with Freire, et al. ${ }^{7}$ (1996), who found that tooth decay was higher in children attending public nursery schools in Goiania, $\mathrm{GO}$, than in those attending private nursery schools, and concluded that an appropriate whole population strategy would include the implementation of a national food policy aimed at reduction of the high levels of sucrose consumption.

The issue of oral hygiene was one which the mothers remembered most. This can be related to the fact that the procedure for cleaning the mouth was demonstrated and supervised by the project team, and thus remained in the mothers' visual memory. The value of starting oral hygiene before the first tooth's eruption on children's toothbrushing habits lacks scientific support. But we believe that early oral hygiene procedures can support the maintenance of this habit, which is therefore encourages.

Another study in Latin America ${ }^{10}$ showed that a prenatal and postnatal prevention program was effective on dental caries prevention after four years. This investigation found that $97 \%$ of the children were caries-free in the experimental group in comparison to $77 \%$ in the control group. Yet, only dental caries was focused, and oral health promotion programs should go far beyond this.

Most mothers remembered the advice to breastfeed their babies, exclusively and on demand, until their sixth month. This may be due mainly to the CFHI campaign, but the LIPD team was also prepared to answer the lying-in women's questions. It is recognized that support and guidance programs on breastfeeding babies should be intensified during pregnancy and puerperium ${ }^{3}$.

Breastfeeding has nutritional implications, benefits host defenses, and has effects on growth, neurodevelopment, and the development of chronic disorders in children ${ }^{17}$.

TABLE 1- Mothers' recall of baby oral health instructions received in their lying-in period

\begin{tabular}{lccc}
\hline Variables & Group A (n) & Group B (n) & p \\
\hline Transmissibility of dental caries from mother to baby & & & 0.158 \\
- Sharing baby utensils & 8 & 5 & 0.089 \\
- Cleaning pacifier with her own saliva & 6 & 3 & 0.327 \\
- Blowing on baby's food & 7 & 7 & 0.158 \\
- Talking very near & 7 & 10 & 0.158 \\
- Kissing the baby's mouth & 10 & 11 & 0.327 \\
Baby's low sugar diet & 17 & 5
\end{tabular}

\section{Baby's oral hygiene}

- Remembered the advice 23

$23 \quad 21$

0.158

- Incorporated the habit

21

17

0.327

\section{Arch development}

- Negative contribution of pacifier

- Vertical position of the baby during breastfeeding

- Enlarging the bottle's nipple hole

- Bottle use avoidance 
Breastfeeding also has beneficial effects on the mother and society in general ${ }^{17}$. Therefore, nowadays breastfeeding promotion should be considered as one of the roles of the dentist.

The reasons that prevented the mothers from breastfeeding their babies until their sixth month confirm the myths that surround the practice of breastfeeding, and were clearly discussed by Carvalho ${ }^{4}$ (1985).

The effect of breastfeeding on infant orofacial development is controversial. Karjalainen, et al. ${ }^{12}$ (1999) showed that the exclusive and total breastfeeding periods of children with posterior crossbite were both significantly shorter than those of other children. They suggested that the early introduction of bottle feeding, indicating a pattern of low-impact muscular activity, may interfere with the normal development of the alveolar ridges and hard palate, and hence lead to posterior crossbite. However, Warren and Bishara ${ }^{21}$ (2002) did not observe any relationship between duration of breastfeeding during the first year of life and dental arch or occlusal parameters.

The ninth step of the "Ten Steps to Successful Breastfeeding” ${ }^{23}$ warns against giving breast substitutes or pacifiers to breastfeeding infants, because they can interfere with the success of breastfeeding. In the study of Soares, et al. ${ }^{19}$ (2003), among the 237 newborns born in a CFHI whose mothers were contacted in the first month of life, $61.6 \%$ had been using pacifiers, most of them since the first week of life. The authors concluded that the use of pacifiers is deeply rooted in our culture, even in a population oriented toward avoiding it, and that there is an association between pacifier use and shorter duration of breastfeeding and exclusive breastfeeding. Conversely, the present results showed that only $9 \%$ of babies up to 6 months old were using a pacifier.

In addition, there is a commonsense belief that it is better for a baby to suck on a pacifier than on a finger, toy or blanket. One study ${ }^{20}$ found that preschool children discontinued pacifier sucking earlier than finger sucking. Moreover, in that study pacifiers showed a preventive effect against finger sucking, since only $2 \%$ of the 316 children examined did both. Other study ${ }^{21}$ showed that prolonged pacifier use resulted in changes to the dental arches and the occlusal parameters that were different from the effects of finger sucking, and that some changes persisted well beyond the cessation of the pacifier or finger-sucking habit. Thus, it is important to prevent a habit from becoming an addiction.

In terms of disseminating the information, the majority of the women passed on to others what they had learned. This is of special importance, since simple but basic knowledge that will result in the healthy development of the baby's mouth is being circulated. And, according to Oliveira Jr, et al. ${ }^{15}$ (1997), a woman who has received correct information becomes an agent for the program, thus multiplying its repercussion within the society she lives in.

Although a statistical analysis did not show any significant differences throughout the period under evaluation, it would be valid to carry out another assessment covering a longer period of time, and a more consistent sample. It is also suggested that follow-up oral health programs should be developed for both mothers and their babies as a means of increasing the level and quality of oral health in these two groups.

The suggestions made by the program team during the counseling visits at the maternity ward are perfectly feasible and can be included in the mothers' daily routine. Thus, considering that 1 ) the mother's and/or caregiver's dental knowledge, attitudes, beliefs and practices affect the child's oral condition ${ }^{2}$, serving as prerequisites to behavioral change, and 2) periodic reinforcement of health education messages is always necessary to counteract the effect of fading over a period of time ${ }^{8}$, it is suggested that no health professional should miss the opportunity of educating families about oral health issues. As far as infant oral health is concerned, it would be advisable to schedule prenatal and neonatal visits, with the second post-natal consultation no later than four months after childbirth.

\section{REFERENCES}

1- Carvalho M. Obstáculos ao aleitamento materno: fatos e mitos. J Pediatr (RJ) 1985; 59:403-14.

2- Chan SCL, Tsai JSJ, King NM. Feeding and oral hygiene habits of preschool children in Hong Kong and their caregivers' dentalknowledge and attitudes. Int J Paediatr Dent 2002; 12:32231.

3- Cordon JA, Bandeira LM, Bezerra ACB. Estudo prospectivo das condições de saúde bucal de crianças nascidas vivas na Regional Norte de Saúde do Distrito Federal. Parte I: o início e as dimensões sócio-econômicas e culturais. Rev Ação Coletiva 1998; 1:27-37.

4- Dias NMO. Mulher, mãe, dona de casa agente de saúde da classe trabalhadora. CCS 1996; 9:63-74.

5- Di Reis IT, Moreira SC. Risco de cárie em bebês. ROBRAC 1995; 5:11-7.

6- Everdingen TV, Eijkman MAJ, Hoogstraten J. Nursing caries: parents and nursing-bottle caries. ASDC J Dent Child 1996;63:2714.

7- Freire MCM, Melo RB, Silva SA. Dental caries prevalence in relation to socioeconomic status of nursery school children in Goiânia-GO, Brazil. Community Dent Oral Epidemiol 1996; 24:357-61.

8- Frenkel HF, Harvey I, Needs KM. Oral health care education and its effect on caregivers' knowledge and attitudes: a randomised controlled trial. Community Dent Oral Epidemiol 2002; 30:91100.

9- Goepferd SJ. An infant oral health program: The first 18 months. Pediatr Dent 1989; 79:21-5.

10- Gomez SS, Weber AA. Effectiveness of a caries preventive program in pregnant women and new mothers on their offspring. Int J Paediatr Dent 2001; 11:117-22. 
11- Jones S, Hussey R, Lennon MA. Dental health behaviours in toddlers in low and high caries areas in St Helens, northwest England. Br Dent J 1996; 181:13-7.

12- Karjalainen S, Ronning O, Lapinleimu H, Simell O. Association between early weaning, non-nutritive sucking habits and occlusal anomalies in 3-year-old Finnish children. Int J Paediatr Dent 1999; 9:69-73.

13- Konishi F. Odontologia intra-uterina. Rev Assoc Paul Cir Dent 1995; 49:135-6.

14- Menino RTM, Bijella VT. Necessidades de saúde bucal em gestantes dos núcleos de saúde de Bauru: conhecimentos com relação à própria saúde bucal. Rev FOB 1995; 3:5-16.

15- Oliveira Jr OB, Ueda JL, Campanelli V, Andrade MF, Saad JRC. Contribuição para a eficácia de programas de prevenção: identificando conhecimento e os mitos sobre saúde bucal em gestantes de classe média de Araraquara. Rev Assoc Maringaense Odont 1997; 1:19-24.

16- Paunio P. Dental health habits of young families from Southwestern Finland. Community Dent Oral Epidemiol 1994; 22: $36-40$

17- Schanler RJ. The evidence for breastfeeding. Pediatr Clin North Am 2001; 48:19A-20A.

18- Slavutzky SMB. Reflexões sobre a relação da cárie com outras doenças crônico degenerativas. Rev Ação Coletiva 1998; 1:12-4.

19- Soares MEM, Giugliani ERJ, Braun ML, Salgado ACN, Oliveira AP, Aguiar PR. Uso de chupeta e sua relação com o desmame precoce em população de crianças nascidas em Hospital Amigo da Criança. J Pediatr (RJ) 2003; 79:309-16.

20- Vadiakas G, Oulis C, Berdouses E. Profile of non-nutritive sucking habits in relation to nursing behavior in pre-school children. J Clin Pediatr Dent 1998; 22:133-6.

21- Warren JJ, Bishara SE. Duration of nutritive and nonnutritive sucking behaviors and their effects on the dental arches in the primary dentition. Am J Orthod Dentofacial Orthop 2002; 121:347-56.

22- Weinstein P. Public health issues in early childhood caries. Community Dent Oral Epidemiol 1998; 26: 84-90.

23- World Health Organization/Division of Child Health and Development. Evidence for the Ten Steps to Successful Breastfeeding. Geneva: WHO, 1998. 